\section{Seed priming with salicylic acid potentiates water restriction- induced effects in tomato seed germination and early seedling growth}

\author{
Yutcelia Carolina Galviz-Fajardo ${ }^{1^{*}}$ (D), Gabriel Streck Bortolin ${ }^{2}$, Sidnei \\ Deuner $^{1}\left(\mathbb{D}\right.$, Luciano do Amarante ${ }^{1}\left(\mathbb{D}\right.$, Fernanda Reolon ${ }^{1}$ (D), Dario Munt \\ de Moraes ${ }^{1}$ (iD
}

ABSTRACT: Seed priming with salicylic acid (SA) has been described as a method with potential to improve seed germination under unfavorable conditions. The present study aimed to evaluate the ability of seed priming with SA to attenuate the impact of water restriction during germination and early seedling growth of tomato. Seeds were subjected to different concentrations of SA $(0,25$ and $50 \mu \mathrm{M})$ and sowed on substrates at different percentages of the water holding capacity (20, $30,40$ and $100 \%)$. The following variables were evaluated: germination, first count of germination, germination speed index, shoots/root length and dry mass, superoxide dismutase, ascorbate peroxidase and catalase activities, contents of hydrogen peroxide and of malondialdehyde. Water restriction significantly decreased the variables related to germination and seedling performance. Despite increasing germination speed and seedling development when combined with well-irrigated conditions, priming with SA negatively impacted those characteristics under water deficit conditions. That was through increases in superoxide dismutase activity and $\mathrm{H}_{2} \mathrm{O}_{2}$ accumulation. Thus, it was concluded that seed priming with SA does not improve tomato seed germination and early seedling growth under water deficit.

Index terms: antioxidant activity, drought stress, phytohormone, priming agent, ROS, Solanum lycopersicum L.

O condicionamento de sementes com ácido salicílico potencializa os efeitos induzidos pela restrição hídrica na germinação e crescimento inicial de plântulas de tomate

RESUMO: O priming de sementes com ácido salicílico (AS) tem sido descrito como um método com potencial para melhorar a germinação sob condições desfavoráveis. Objetivou-se avaliar a capacidade do condicionamento com AS em atenuar o impacto da restrição hídrica durante a germinação e crescimento inicial de plântulas de tomate. As sementes foram submetidas a distintas concentrações de AS $(0,25$ e $50 \mu \mathrm{M})$ e semeadas em substratos a diferentes percentagens da capacidade de restrição de água (20,30, 40 e 100\%). As variáveis avaliadas foram: germinação, primeira contagem de germinação, índice de velocidade de germinação, comprimento e massa seca da parte aérea/raiz, atividades de superóxido dismutase, ascorbato peroxidase e catalase, conteúdos de peróxido de hidrogênio e malondialdeído. A restrição hídrica diminuiu significativamente as variáveis relacionadas à germinação e o desempenho das plântulas. Apesar de incrementar a velocidade de germinação e o desenvolvimento das plântulas quando aplicado em condições bem irrigadas, o priming com AS impactou negativamente tais características sob condições de déficit hídrico. Isto através de aumentos na atividade da superóxido dismutase e acumulação de $\mathrm{H}_{2} \mathrm{O}_{2}$. Assim, conclui-se que o condicionamento de sementes com AS não aprimora a germinação e crescimento inicial de plântulas de tomate sob condições de déficit hídrico.

Termos para indexação: atividade antioxidante, estresse hídrico, fitohormônio, agente priming, EROs, Solanum lycopersicum L..
Journal of Seed Science, v.42, e202042031, 2020

http://dx.doi.org/10.1590/ 2317-1545v42234256 


\section{INTRODUCTION}

Tomato (Solanum lycopersicum L.) is one of the most important extensively horticultural crops, ranked second after potato in terms of production and consumption worldwide (Singh et al., 2018). Its current world production is about 182.3 million tons of fresh fruit (FAOSTAT, 2019), with the majority of production coming from countries located mainly between subtropical and temperate zones. With an annual production of 4.08 million tons (IBGE, 2020), Brazil is among the ten largest producers of this fruit.

As a tropical plant, the tomato species is well adapted to almost all climatic regions; however, environmental stress remains a primary constraint of tomato potential yield and quality (Ronga et al., 2018). Most tomato varieties are sensitive to drought stress, especially during early growth stages (George et al., 2013), which include seed germination and seedling initial growth. Due to the increasing global demand for fresh fruits and vegetables, the cultivation of tomatoes has been expanded, especially in semi-arid and arid regions where recurrent drought and water shortages are quite common (Kumar et al., 2017). Such cultivation requires precise water requirement estimates and adaptations of the irrigation program based on the needs of the plant and its growth conditions, leading to increase water use efficiency (Hooshmand et al., 2019).

During seed germination, salt and osmotic stresses are responsible for both inhibition or delayed seed germination and seedling establishment (Lopes et al., 2019; Silva et al., 2019). Producing plants that can withstand these stresses is a considerable challenge; therefore the development of scientific strategies for minimizing damages due to low water availability is warranted. One of the most used pre-sowing procedures to benefit seed germination is a process known as seed priming. Seed priming technology is widely used to synchronize germination, reduce emergence time, and improve crop establishment under stressful conditions (Ibrahim, 2016). Different types of molecules can be used in seed priming to promote tolerance to various abiotic stresses, including the stress associated with drought (Zheng et al., 2016). Growth regulators, among them salicylic acid (SA), have been used to increase seed germination and seedling performance in different crops. The mechanisms by which the SA generates these improvements are related to the protection of cell membranes, increases in carbon metabolism, antioxidant system, osmoprotection and photosynthetic pigments (Sharma et al., 2017), and the regulation of stress defense proteins such as glutathione S-transferases, APX and 2-cysteine peroxiredoxin (Kang et al., 2012). Senaratna et al. (2000) reported that seed priming with SA in tomato plants exposed to drought induced the capacity to retain a relatively high degree of turgidity and recovery upon watering. In regards to water scarcity however, little is known about the effects of pre-treatment with SA on tomato seed germination under this condition. In the present study, we investigate whether SA could be used to improve tomato seed germination and early seedling establishment under water restriction conditions, as well as further examine the biochemical changes underlying the germination process.

\section{MATERIAL AND METHODS}

\section{Plant material and AS-water treatments}

The experiment was carried out at the Seed Physiology Laboratory of the Universidade Federal de Pelotas (UFPel), Rio Grande do Sul, Brazil. One lot of commercial seeds of tomato (Solanum lycopersicum L.) v. Gaúcho/Maçã was used. The seeds were obtained in the 2018 harvest with germination of $93 \%$.

To evaluate the responses of tomato seeds to priming with SA and drought during germination, the germination of primed seeds with SA of different concentrations $(0,5,25,50,250,500$ and $1000 \mu \mathrm{M})$ or under different WHC levels $(5,10,15,20,30$ up 100\%) was analyzed. For further experimentation, SA concentrations of 0,25 and $50 \mu \mathrm{M}$ and WHC levels of $20,30,40 \%$ and $100 \%$ for priming and water restriction treatments were used, respectively.

Firstly, seeds were embedded in SA aerated solutions at the following concentrations: $0 \mu \mathrm{M}$ (priming with water), $25 \mu \mathrm{M}$ and $50 \mu \mathrm{M}$ for 60 minutes. Seeds were then dried and stored under controlled conditions $\left(15^{\circ} \mathrm{C} ; 40-50 \% \mathrm{RH}\right)$ for 
24 hours. Previous the installation of assays, determination of seed moisture content was completed using the oven drying method ( $105^{\circ} \mathrm{C}$ for $24 \mathrm{~h}$ ), before and after the priming with SA (Brasil, 2009). Moisture content of tomato seed previous seed priming was equal to 8.28 and after seed priming was $9.61,9.32$ and 9.33 for the SA solutions of 0,25 and $50 \mu \mathrm{M}$, respectively. Thus ensuring that seed water content did not change enough to alter its physiological activity (Marcos-Filho, 2015).

Factor levels of water restriction were imposed using MecPlant ${ }^{\circledR}$ commercial substrate for horticultural seedlings at different water holding capacities (WHC: 20, 30, 40 and 100\%) determined by gravimetric method (Cooper, 2016). The pine-bark/vermiculite based substrate had the following characteristics: $\mathrm{pH}=5.3-5.8 ; \mathrm{EC}=1.2-1.7 \mathrm{dS} . \mathrm{m}^{-1}$; granulometry < $06 \mathrm{~mm}$; density $=375 \mathrm{~g} . \mathrm{L}^{-1}$. With the aid of an $\mathrm{ECH}_{2} \mathrm{O}$ soil moisture sensors coupled to an $\mathrm{ECH}_{2} \mathrm{O}$ Check (Decagon Devices, Pullman, WA) was determined the volumetric water content percentage equivalent to every WHC of the substrate, being $20,30,40$ and 100 WHC equal to of 2.25, 4.66, 7.08 and 21.57, respectively. Moisture control was carried out daily by weighing the substrate and replenishing when necessary using a water sprayer to ensure uniform application.

\section{Analysis of germination rate and seedling weight and length}

A germination test was conducted using primed seeds (AS: 0,25 and $50 \mu \mathrm{M}$ ) that were germinated in plastic germination boxes $(11 \mathrm{~cm} \times 11 \mathrm{~cm} \times 3.5 \mathrm{~cm})$ filled with substrate at the various WHC treatment levels. Each treatment consisted of three replicates divided in four subsamples of 50 seeds. Seeds were partially sunk but not covered by the substrate and maintained in germination chambers for photoperiods of $12 \mathrm{~h}$ (light) $/ 12 \mathrm{~h}$ (dark), at $30^{\circ} \mathrm{C} / 20^{\circ} \mathrm{C}$ (Brasil, 2009).

Germination (G) percentage was determined following the Rules for Seed Testing (Brasil, 2009), by counting the number of germinated seeds at 14 days after sowing (DAS) using percentage of normal seedlings as the assessment criterion. First germination count (FGC) was determined at 5 DAS. Germination speed index (GSI) was also complementarily computed using the Maguire (1962) equation, for this variable, the criterion for considering a seed as germinated was the radicle visibly protruded from the seed coat by at least $2 \mathrm{~mm}$.

Shoot and root lengths were measured in 14-day-old seedlings (120 from each treatment). Lengths were measured with a millimeter ruler. Seedlings were separated into shoots or roots, and then the various parts were packed in kraft bags and placed in a forced air circulation oven at $60 \pm 2{ }^{\circ} \mathrm{C}$ until they reach constant mass and subsequently weighed on an analytical balance $(0.001 \mathrm{~g})$ to determine dry weight (Nakagawa, 1999).

\section{Biochemical analyses}

For antioxidant activity, tomato seeds collected at 48 hours after sowing were ground to a powder with a mortar and pestle with liquid nitrogen and homogenized with $20 \%(\mathrm{w} / \mathrm{v})$ polyvinylpolypyrrolidone (PVPP) and $0.1 \mathrm{M}$ potassium phosphate buffer ( $\mathrm{pH} 7.8$ ) containing $0.1 \mathrm{mM}$ ethylenediaminetetraacetic acid (EDTA) and $0.02 \mathrm{M}$ ascorbic acid. The homogenate was centrifuged at $12,000 \times g$ for $20 \mathrm{~min}$ at $4{ }^{\circ} \mathrm{C}$. The supernatant was used for enzyme assays. Total protein concentration was determined according to the Bradford method (1976). The activity of superoxide dismutase (EC.1.15.1.1) was measured according to a method of Giannopolitis and Ries (1977). The activity of ascorbate peroxidase (EC 1.11.1.11) was assayed as described by Nakano and Asada (1981) and catalase (EC 1.11.1.6) activity was assayed according to the method described by Aebi (1983).

Seed fresh matter collected at 48 hours after sowing was homogenized on liquid nitrogen with a mortar and pestle in $0.1 \%(\mathrm{w} / \mathrm{v})$ trichloroacetic acid (TCA). The homogenate was centrifuged at $12,000 \times \mathrm{g}$ for $20 \mathrm{~min}$ at $4{ }^{\circ} \mathrm{C}$ and the supernatant used immediately for the following procedures. Lipid peroxidation was measured using a thiobarbituric acid (TBA) method (Cakmak and Horst, 1991). The concentration of malondialdehyde (MDA) was calculated as a measure of lipid peroxidation. The $\mathrm{H}_{2} \mathrm{O}_{2}$ content in tomato seeds was assessed using the Velikova et al. (2000) method.

\section{Statistical analyses}

Each treatment consisted of a minimum of three biological replicates, in a completely randomized design. Data were analyzed in a $3 \times 4$ factorial scheme ( 3 SA concentrations $\times 4$ levels of WHC). The data were submitted to tests of 
normality. When they met this assumption, measurements were subjected to analysis of variance (ANOVA) to discriminate any significant differences $(p<0.05)$ and means were compared by Tukey test $(5 \%)$ using the SISVAR 5.6 statistical software program (Ferreira, 2014). Furthermore, principal component analysis (PCA) was performed to examine the relationships between variables and observations using the PAST (PAleontological STatistics) software version 3.20.

\section{RESULTS AND DISCUSSION}

The germination of tomato seeds was considerably affected by treatments, priming and WHC, and the interaction between these factors. Although the higher water availability was the most suitable for germination, there were differences in the germination pattern for the three SA concentrations used in each level of substrate moisture content (Figures $1 \mathrm{~A}, \mathrm{C}$ and $\mathrm{E}$ ). In tomato seeds primed with water $(\mathrm{SA} 0 \mu \mathrm{M})$, the germination increased with water content enhancement (Figure 1B). The treatment of WHC $40 \%$ did not differ statistically from control (WHC 100\%) and both favored the percentage of germination. However, in the treatments of WHC $20 \%$ and $30 \%$ the $\mathrm{G}$ was $12 \%$ and $8 \%$ lower than the control, respectively. When SA 25 or $50 \mu \mathrm{M}$ was applied, the responses in the water levels differed. First, it was observed that these concentrations combined with the level of WHC $100 \%$ had germination values statistically equal to those of water priming. Second, higher concentrations of SA reduced G in water restriction levels, i.e. in WHC $40 \%$, $30 \%$ and $20 \%$, in this last level there was germination equal to $0 \%$.

Seed priming with salicylic acid has been reported as a strategy to improve germination under drought conditions in rice (Li and Zhang, 2012; Samota et al., 2017) and wheat (Sharafizad et al., 2013) and to decrease the inhibitory effect of drought stress in tomato cv. Romano and beans (Senaratna et al., 2000). However, in this study, SA was observed to have an inhibitory effect when applied in combination with restricted water levels. This response could be associated also with the species/cultivar used as well as the time and duration when the water deficit was imposed in each experiment. On the other hand, the results of this work are in agreement with other studies indicate that SA could inhibit the germination of Arabidopsis, barley and corn (Rivas-San Vicente and Plasencia, 2011), by modulating the expression of enzymes such as catalase or potentiate the stress response of the germinating seedling (Pokotylo et al., 2019).

SA and drought generated a synergic action inhibiting tomato seed germination. It is known that the imbibition phase re-actives enzymes involved in seed reserve mobilization in order to sustain embryo growth. Tomato seed endosperm contains large amounts of galacto(gluco)mannans, and the weakening of this endosperm cap by enzymatic hydrolysis, results from the activity of endo- $\beta$-mannanase, $\beta$-mannosidase and $\alpha$-galactosidase, specially the endo$\beta$-mannanase activity has been generally recognized as marker for tomato germination (Moles et al., 2019). In some species, that requires the activity of this enzyme to germinate, have been reported that its production is inhibited by increasing concentrations of salicylic acid (Kontos and Spyropoulos, 1996).

First germination count as a variable showed interdependence between the factors studied. Pre-soaked seeds in water, when sowed at the lowest WHC, showed a 72\% decrease in relation to the control of WHC (Figure 1D). In the combination treatment of SA $0 \mu \mathrm{M}$ and low levels of WHC, the FGC was always higher compared to SA 25 and 50 $\mu \mathrm{M}$, which reached values close to zero, while at WHC $100 \%$ there was no difference. The germination speed index presented significance in the interaction between SA and WHC, always being higher in WHC $100 \%$ treatments, with or without SA, and decreasing as water content decreased (Figure 1F). A GSI reduction was observed in seeds primed with water and WHC 20\% (0.45-fold lower than at WHC 100\%). Treatments of SA 25 and $50 \mu \mathrm{M}$ with WHC $30 \%$ and $40 \%$ resulted in lower GSI, which were 16 and 4 times lower than with no SA, respectively. On the other hand, in WHC $100 \%$ the GSI was significantly higher in seeds conditioned with SA at $50 \mu \mathrm{M}$ (1.2-fold higher). Additionally, the daily computation for GSI allowed observing that, when increasing SA concentrations were applied at WHC $100 \%$, the emergence of the radicle was anticipated from the third day (Figure 1A) to the second after sowing (Figures 1C-E).

Germination processes are dependent on the water potential of the substrate, as the water potential is reduced, the seeds need a longer time to complete the imbibition process and to germinate (Pereira et al., 2012). Also, it is related 

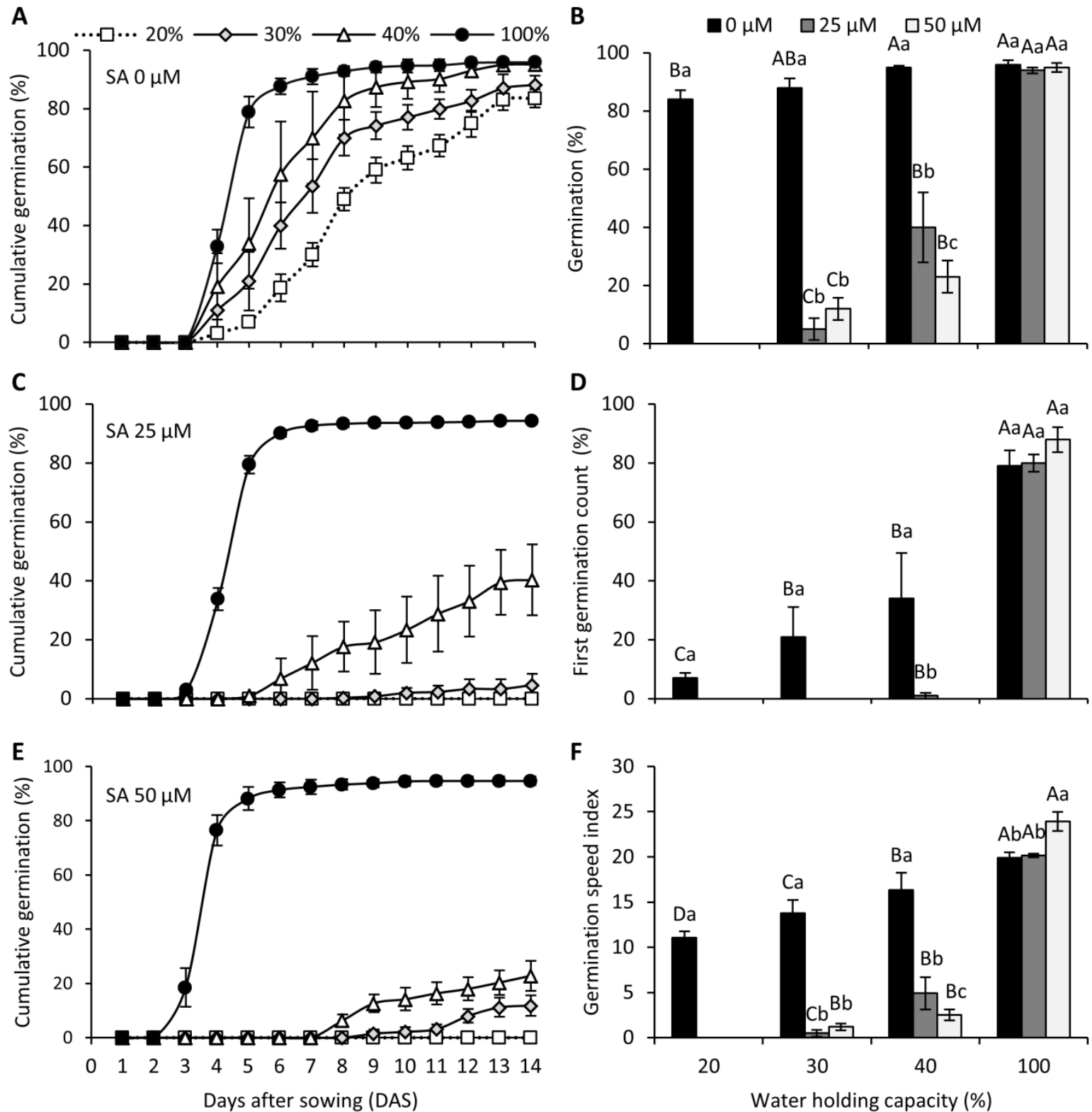

Figure 1. Effects of seed priming with $\mathrm{SA}$ and levels of WHC on tomato seed germination. Daily accumulated germination

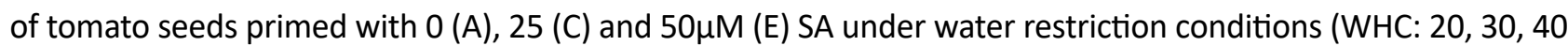
and $100 \%)$. Germination (G) percentage of tomato seeds at day 14 (B). First germination count (FGC) of tomato seeds at day 5 (D). Germination rate index (GSI) of tomato seeds (F). Each data presents the mean \pm standard deviation. Different uppercase letters indicate significant statistical differences between the WHC treatments; different lowercase letters indicate significant statistical differences between the SA treatments $(p<0.05)$.

about the importance of the concentration of SA used for improve seed treatment according to the species studied. In tomatoes, Hayat et al. (2008) found that plants subjected to water limitation were benefited by the application of SA of $10 \mu \mathrm{M}$, Senaratna et al. (2000) showed that concentrations between 100-500 $\mu \mathrm{M}$ of SA induced a tolerance to multiple stresses, Gharbi et al. (2018) improved tolerance to salt stress using $10 \mu \mathrm{M}$ of SA. In none of these studies was applied seed priming with SA and water limitation simultaneously. Thus, these findings suggest that SA concentrations that result in beneficial for tomato plants under well-watered conditions (in the present work) and stressed conditions in already established plants (in the referenced works) did not mitigate the effects of water restriction during seed germination. 
The shoot dry weight and, in a greater extent the shoot length, of tomato seedlings were significantly shortened by the lower WHC and, in different ways, by SA priming. Root dry weight and length were not influenced by WHC levels, but they were affected by SA concentrations (Figure 2). Seedlings showed higher shoot length as water content increased (Figure 2A), with the highest dry weight being found at WHC 100\% (Figure 2B).

It is known that the development of shoots can be affected by the availability of water in the soil, which negatively affects the mobilization of seed reserves to the seedling reducing its growth and development (Morais et al., 2020), consequently reducing its growth and development. SA application in treatments of WHC $40 \%$ resulted in up to $47 \%$ decrease of shoot growth. This decrease of shoot length and dry weight of seedlings germinated from seeds treated with increasing doses of SA and WHC $40 \%$, could be a product of late germination as well as of oxidative stress induced by the application of SA. Even though the root length and dry weight of the seedlings were equal at different WHC levels, the SA application tended to decrease the length and increase slightly the root biomass. Interestingly, seedlings treated with the combination of SA and WHC $100 \%$ exhibited higher shoot length (up 12\%). Previous works indicate that seedling performance is improved by SA priming in wheat and bean seedlings (Hayat et al., 2008; Agostini et al., 2013; Yamamoto et al., 2014). This is due to the increase in the activity of many enzymes involved in the metabolism of carbohydrates, proteins and lipids, involved in the mobilization of stored reserves condition that allows the early and superior emergence of seedlings (Varier et al., 2010; Sharma et al., 2017).

Results showed that SOD activity was significantly affected by water content and also by SA priming, and the interactions between these treatments (Figure 3A). Seeds from priming with water had lower activities of SOD, the lowest being at WHC 30\% ( 40\% lower than for other WHC levels). Priming with SA 25 and $50 \mu$ M increased the SOD activity, with emphasis in the combination treatment with WHC 20\%, where an increase of approximately two times its activity was observed. SOD activity was also higher in WHC 30, 40 and $100 \%$ when compared to those without SA (2.19-
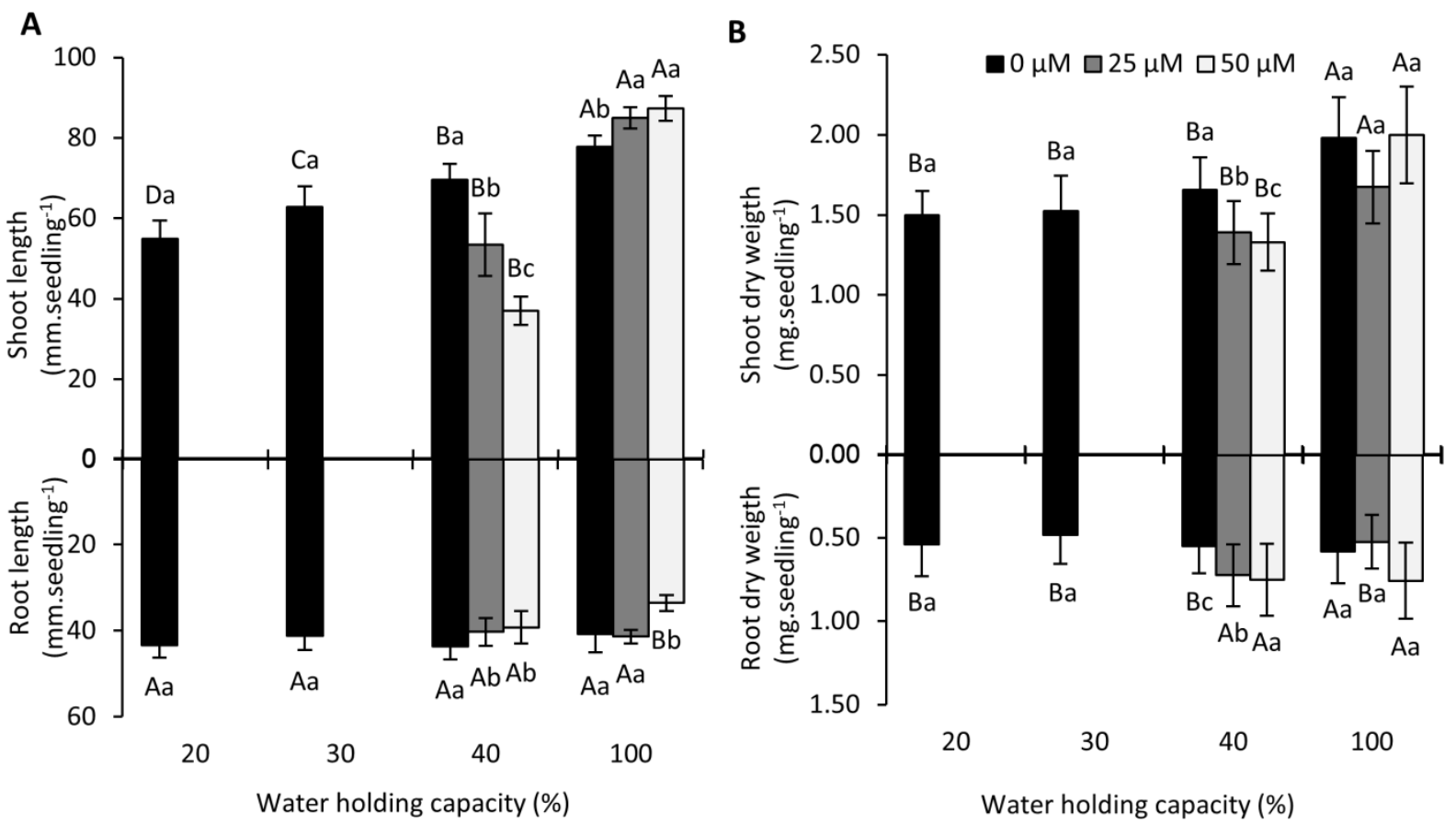

Figure 2. Effects of seed priming with SA and levels of WHC on tomato seedling growth. Length of shoots and roots of tomato seedlings at 14 DAS (A). Fresh weight of shoots and roots of tomato seedlings at 14 DAS (B). Each data presents the mean \pm standard deviation. Different uppercase letters indicate significant statistical differences between the WHC treatments; different lowercase letters indicate significant statistical differences between the SA treatments $(p<0.05)$. 
A

$0 \mu \mathrm{M} \square 25 \mu \mathrm{M} \square 50 \mu \mathrm{M}$
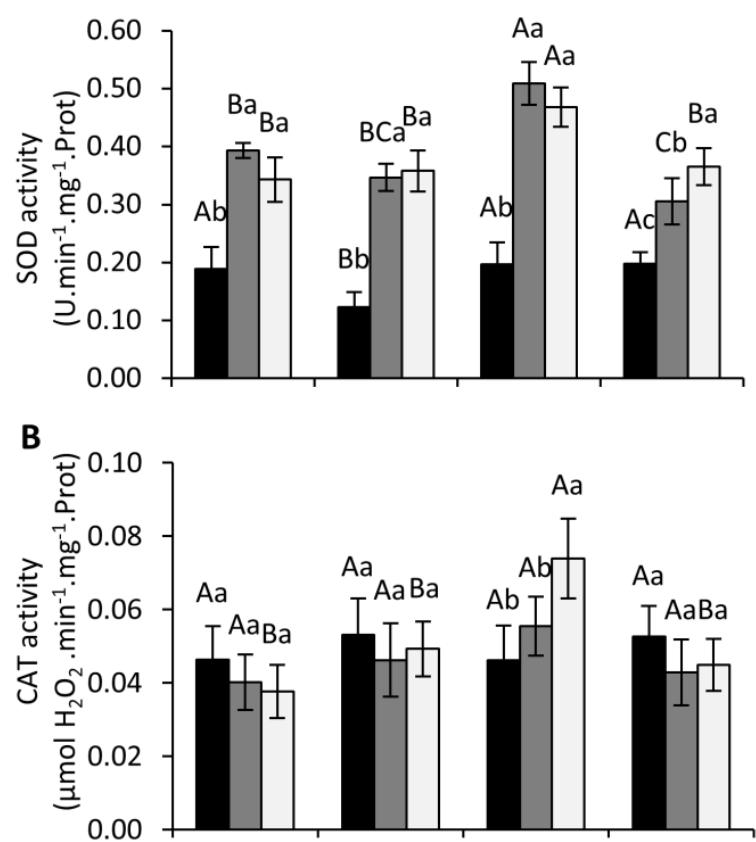

C

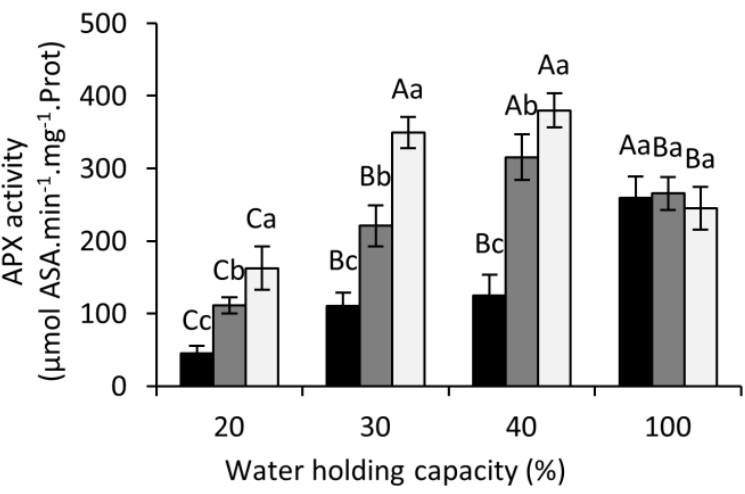

Figure 3. Effects of seed priming with SA and levels of WHC on tomato seed antioxidant activity. Enzimatic activities of SOD (A), CAT (B) and APX (C). Each data presents the mean \pm standard deviation. Different uppercase letters indicate significant statistical differences between the WHC treatments; different lowercase letters indicate significant statistical differences between the SA treatments $(p<0.05)$.

fold, 1.25-fold and 0.7-fold activity increases respectively). Activation of enzymatic antioxidants is commonly related to the reduction of ROS-induced oxidative damages (Ibrahim, 2016). SA induced higher SOD activities in all WHC levels, an enzyme that is known to be the first involved in the defense system, converting superoxide anion to $\mathrm{H}_{2} \mathrm{O}_{2}$, activating from this moment the action of secondary neutralizing enzymes, such as CAT, APX and GPX (Pereira et al., 2012).

The activity of CAT remained almost unchanged for the different combinations of SA and WHC (Figure 3B). There was no influence observed for the different levels of SA in water contents of 20,30 and $100 \%$. When sown at WHC $40 \%$ and primed with SA $50 \mu \mathrm{M}$, enzymatic activity was found to be significantly higher ( $45 \%$ higher). Studies indicate that the activity of CAT is correlated with the rate of germination of tomato seeds (Badek et al., 2016).

APX activity was influenced by both factors applied. As shown in Figure 3C, the enzymatic activity was enhanced by the increase of water in substrate. In seeds primed with water, the enzyme reached its highest activity at WHC $100 \%$ (4.7-fold higher). Research refers to the inactivity of the APX in quiescent seeds emphasizing that its activity begins a 
few hours after the beginning of the imbibition (Pires et al., 2016) and the rapid recovery of its activity is crucial for seed germination and early development of seedlings (Fercha et al., 2014). In this way, a connection can be made between the increase of water in the substrate, a faster imbibition and consequently, activation of the APX, as observed by Morais et al. (2020). SA concentrations used for priming seeds germinated under water restrictions enhanced the activity of APX (1.3-fold and 2.2-fold for SA 25 and $50 \mu \mathrm{M}$, respectively). SA concentrations have no effect in this variable at WHC $100 \%$.

Lipid peroxidation assessed by malondialdehyde (MDA) content in seeds showed significant differences as a result of SA and WHC treatments (Figure 4A). In seeds primed with water, MDA content was increased under water restriction treatments and was lowest in WHC 100\% ( 25\% lower). SA priming in tomato seeds reduced levels of MDA in WHC 20 and $30 \%$, being 0.25 -fold lower for these treatments. Decreases in lipid peroxidation as a result of priming with SA have also been reported as a product of the activation of antioxidant enzymes (Yan, 2015).

Hydrogen peroxide levels in seeds were also significantly affected by the different treatments and the interactions among them (Figure 4B). Priming with water induced a lower concentration of $\mathrm{H}_{2} \mathrm{O}_{2}$ in seeds sowed at WHC 20\% (0.4fold lower than the other WHC levels). Application of SA resulted in an increase of $\mathrm{H}_{2} \mathrm{O}_{2}$ levels in treatments at WHC $20 \%$ (0.6-fold higher), while at WHC 30\% no effect of SA application was observed. Interestingly, at WHC $40 \%$ this effect was reversed, since the use of SA resulted in a decrease of the content of $\mathrm{H}_{2} \mathrm{O}_{2}$ (about 0.3-fold). However, at WHC $100 \%$ differences in hydrogen peroxide levels were not observed in seeds applied with SA.

Oxidative damage caused by overproduction of ROS is a major problem in water stress conditions (Gill and Tuteja, 2010). $\mathrm{H}_{2} \mathrm{O}_{2}$ accumulation determined in a greater extent the results obtained, product of the increase in SOD activity accompanied by the non-increase in CAT and low-increase in APX activities in SA primed seeds under WHC $20 \%$. The PCA presents a more holistic picture of this relation (Figure 5). This figure allows viewing separation or groups between the different treatments and to quantify those variables that mostly contribute for this classification. Figure 5 shows the first two principal components as accounting for $75.11 \%$ of the variance in the data (having eigenvalues larger than 1). The first principal component explained $55.73 \%$ of the variance of the data. The variables germination, first germination count, speed index, length and dry mass of shoots and roots and also $\mathrm{H}_{2} \mathrm{O}_{2}$ content were strongly correlated and determined to a great extent the distance between the treatments. This first component separated the

A

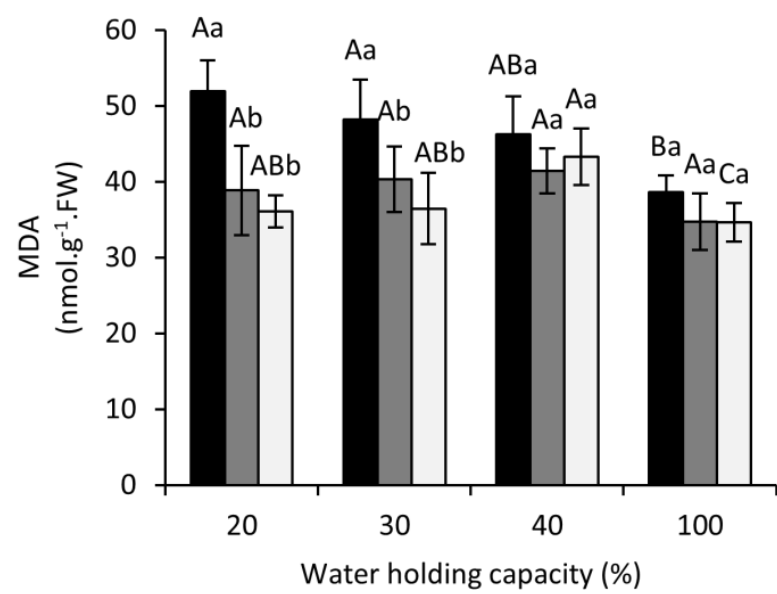

B

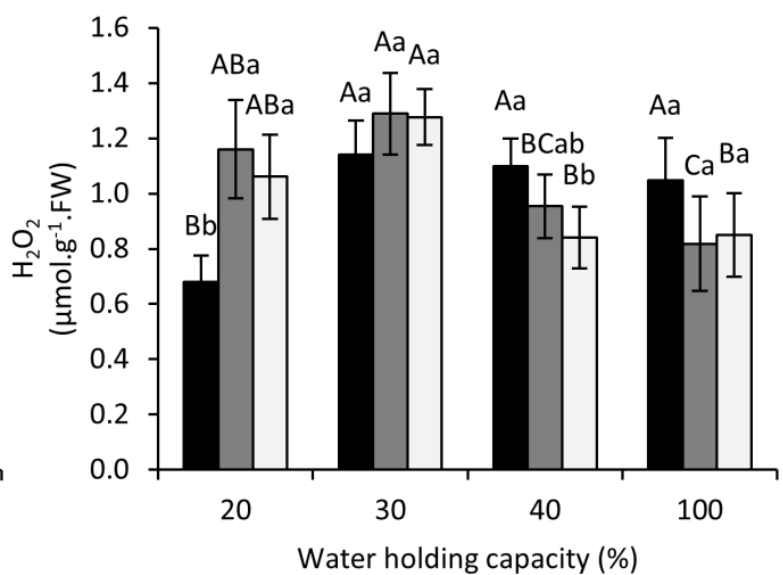

Figure 4. Effects of seed priming with SA and levels of WHC on tomato seed lipid peroxidation and hydrogen peroxide content. Level of MDA (A) and $\mathrm{H}_{2} \mathrm{O}_{2}$ (B) content. Each data presents the mean \pm standard deviation. Different uppercase letters indicate significant statistical differences between the WHC treatments; different lowercase letters indicate significant statistical differences between the SA treatments $(p<0.05)$. 


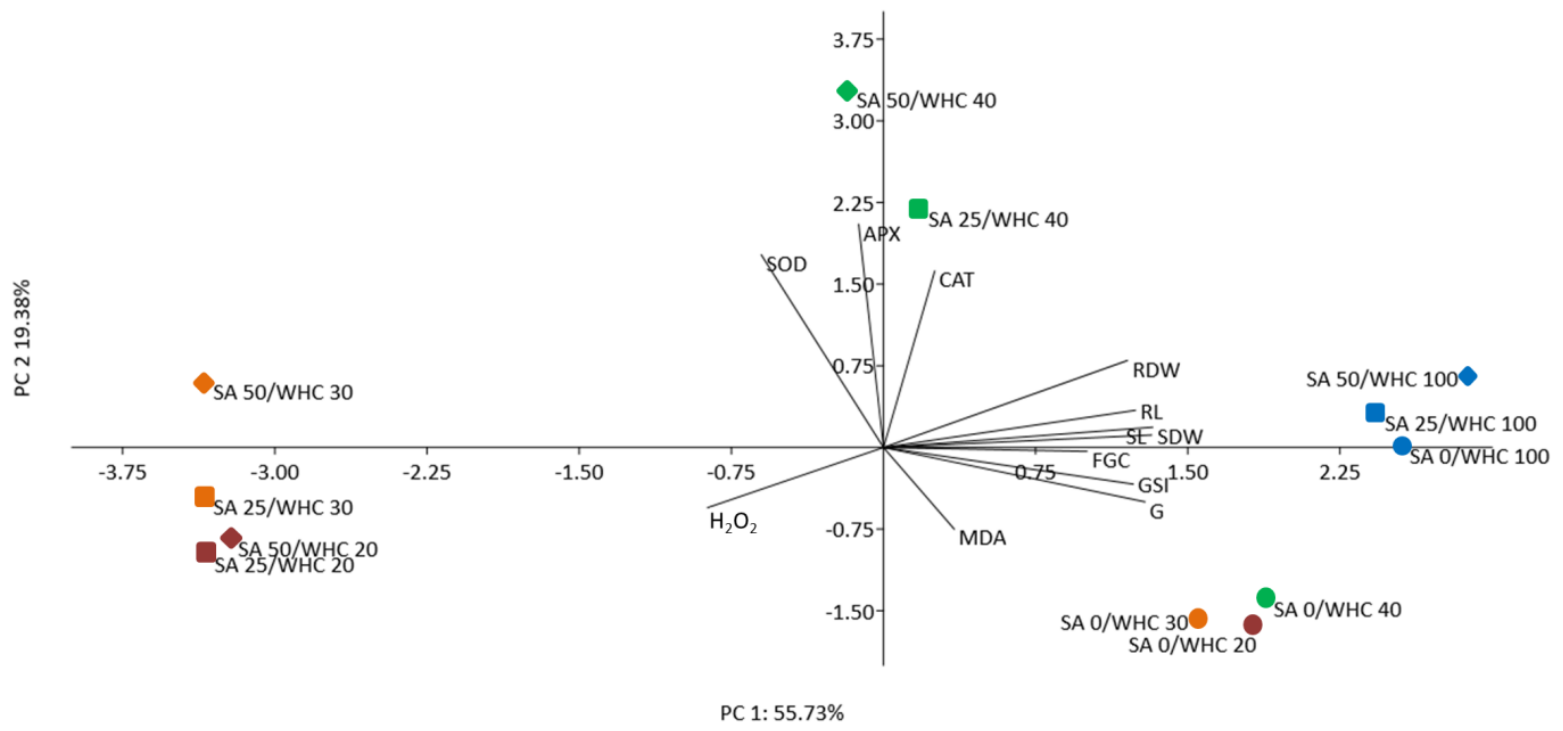

Figure 5. Biplot of the principal component analysis of tomato seeds and seedlings treated with different SA concentrations and sowed under different levels of WHC.

treatments in the biplot between those with no or almost no germination and greater accumulation of $\mathrm{H}_{2} \mathrm{O}_{2}$ (left) and those with higher germination and lower concentrations of $\mathrm{H}_{2} \mathrm{O}_{2}$ (right). The second principal component represents $19.38 \%$ of the remaining variance of the data, being a product to a greater extent of the influence of the activity of the antioxidant enzymes, distributing in the graph the treatments with greater enzymatic activity above the X-axis. Finally, a third principal component not represented in the graph but with an eigenvalue higher than 1 , was defined to a great extent by the MDA content variable, which was strongly related to the treatments of SA $0 \mu \mathrm{M}$ and water restriction.

This result agrees with those reported in the cases of Arabidopsis (Li et al., 2020) and rice (Chao et al., 2010), where there was an increase in hydrogen peroxide levels by the increase of SOD activity, as well as the inactivation of degrading enzymes of $\mathrm{H}_{2} \mathrm{O}_{2}$, catalase among them. ROS are involved as signal molecules in a series of important biological processes including induction of germination and dormancy relief. However, in severe environmental stresses, overproduction of these results in damage to seed development and suppresses germination of mature seeds (Wojtyla et al., 2016). During seed germination, due to various processes, such as the degradation of fatty acids in glyoxylate cycle, it is necessary a high expression and activity of CAT related to the removal of $\mathrm{H}_{2} \mathrm{O}_{2}$ (Mhamdi et al., 2010; Anjum et al., 2016). While studying two tomatoes genotypes, Moles et al. (2019) concluded that increases in catalase activity coped with high hydrogen peroxide content in one genotype, contributing to scavenge oxidative stress and allowing the germination completion. Conversely, in other genotype with lower catalase activity, seeds were impaired by the stress to conclude properly the germination process. Shi et al. (2014) even suggest that CAT plays more important role than other enzymes in scavenging excessive hydrogen peroxide in water stress conditions. Thus, although the activity of CAT and APX were not inhibited by SA, it is logical to think that increases in hydrogen peroxide would consequently require an increase in the activity of these enzymes to complete the germination process under stress.

\section{CONCLUSIONS}

Levels of WHC equal or below to $30 \%$ reduce the germination of tomato seeds.

Seed priming with SA 25 or $50 \mu \mathrm{M}$ enhance GSI and seedling shoot length at WHC $100 \%$. However when combined with water deficit levels, both decrease G, FCG, GSI, and seedling development at the same time as increase $\mathrm{H}_{2} \mathrm{O}_{2}$ content, SOD and APX activity. 
In summary, salicylic acid did not induce tolerance to water restriction in tomato seeds and seedlings. In contrast, SA potentiates the effects induced by water restriction during the germination process.

\section{ACKNOWLEDGMENTS}

This study was financed in part by the Coordenação de Aperfeiçoamento de Pessoal de Nível Superior (CAPES), finance code 001.

\section{REFERENCES}

AEBI, H.E. Catalase. In: BERGMEYER, H.U. (Ed.). Methods of Enzymatic Analysis. Weinheim: Verlag Chemie, 1983. p. 273-286.

AGOSTINI, E.A.T.; MACHADO-NETO, N.B.; CUSTÓDIO, C.C. Induction of water deficit tolerance by cold shock and salicylic acid during germination in the common bean. Acta Scientiarum Agronomy, v.35, n.2, p.209-219, 2013. https://doi.org/10.4025/actasciagron. v35i2.15967

ANJUM, N.A.; SHARMA, P.; GILL, S.S.; HASANUZZAMAN, M.; KHAN, E.A.; KACHHAP, K.; MOHAMED, A.A.; THANGAVEL, P.; DEVI, G.D.; VASUDHEVAN, P.; SOFO, A.; KHAN, N.A.; MISRA, A.N.; LUKATKIN, A.S.; SINGH, H.P.; PEREIRA, E.; TUTEJA, N. Catalase and ascorbate peroxidase-representative $\mathrm{H}_{2} \mathrm{O}_{2}$-detoxifying heme enzymes in plants. Environmental Science and Pollution Research, v.23, p.19002-19029, 2016. https://doi.org/10.1007/s11356-016-7309-6

BADEK, B.; ROMANOWSKA-DUDA, Z.; GRZESIK, M.; KURAS, A. Physiological markers for assessing germinability of Lycopersicon esculentum seeds primed by environment-friendly methods. Polish Journal of Environmental Studies, v.25, n.5, p.1831-1838, 2016. https://doi.org/10.15244/pjoes/63065

BRADFORD, M.M. A rapid and sensitive method for the quantitation of microgram quantities of protein utilizing the principle of protein-dye binding. Analytical Biochemistry, v.72, n.1-2, p.248-254, 1976. https://doi.org/10.1016/0003-2697(76)90527-3

BRASIL. Ministério da Agricultura, Pecuária e Abastecimento. Regras para análise de sementes. Ministério da Agricultura, Pecuária e Abastecimento. Secretaria de Defesa Agropecuária. Brasília: MAPA/ACS, 2009. 395p. https://www.abrates.org.br/files/regras_ analise_de_sementes.pdf

CAKMAK, I.; HORST, W.J. Effect of aluminium on lipid peroxidation, superoxide dismutase, catalase, and peroxidase activities in root tips of soybean (Glycine max). Physiologia Plantarum, v.83, n.3, p.463-468, 1991. https://doi.org/10.1111/j.1399-3054.1991. tb00121.x

CHAO, Y.; CHEN, C.; HUANG, W.; KAO, C.H. Salicylic acid-mediated hydrogen peroxide accumulation and protection against Cd toxicity in rice leaves. Plant Soil, v.329, p.327-337, 2010. https://doi.org/10.1007/s11104-009-0161-4

COOPER, J.D. Gravimetric Method. In: COOPER, J.D. (Ed.). Soil Water Measurement: A Practical Handbook. Nova Jersey: John Wiley \& Sons, 2016. p. 26-42.

FAOSTAT. Food and Agriculture Organization of the United Nations. Tomato World Production. http://www.fao.org/faostat/ en/\#data/QC. Accessed 29 November 2019.

FERCHA, A.; CAPRIOTTI, A.L.; CARUSO, G.; CAVALIERE, C.; SAMPERI, R.; STAMPACHIACCHIERE, S.; LAGANÀ, A. Comparative analysis of metabolic proteome variation in ascorbate-primed and unprimed wheat seeds during germination under salt stress. Journal of Proteomics, v.108, p.238-257, 2014. https://doi.org/10.1016/j.jprot.2014.04.040

FERREIRA, D.F. Sisvar : A guide for its bootstrap procedures in multiple comparisons. Ciência e Agrotecnologia, v.38, p.109-112, 2014. https://doi.org/10.1590/S1413-70542014000200001

GEORGE, S.; JATOI, S.A.; SIDDIQUI, S.U. Genotypic differences against PEG simulated drought stress in tomato. Pakistan Journal of Botany, v.45, n.5, p.1551-1556, 2013. http://www.pakbs.org/pjbot/PDFs/45(5)/10.pdf

GHARBI, E.; LUTTS, S.; DAILLY, H.; QUINET, M. Comparison between the impacts of two different modes of salicylic acid application on tomato (Solanum lycopersicum) responses to salinity. Plant Signaling \& Behavior, v.13, n.5, e1469361, 2018. https://www. tandfonline.com/doi/full/10.1080/15592324.2018.1469361

GIANNOPOLITIS, C.N.; RIES, S.K. Superoxide dismutases. Plant Physiology, v.59, p.309-314, 1977. https://doi.org/10.1104/ pp.59.2.309 
GILL, S.S.; TUTEJA, N. Reactive oxygen species and antioxidant machinery in abiotic stress tolerance in crop plants. Plant Physiology and Biochemistry, v.48, p.909-930, 2010. https://doi.org/10.1016/j.plaphy.2010.08.016

HAYAT, S.; HASAN, S.A.; FARIDUDDIN, Q.; AHMAD, A. Growth of tomato (Lycopersicon esculentum) in response to salicylic acid under water stress. Journal of Plant Interactions, v.3, n.4, p.297-304, 2008. https://www.tandfonline.com/doi/full/10.1080/17429140802320797

HOOSHMAND, M.; ALBAJI, M.; BOROOMAND NASAB, S.; ANSARI, N.A. The effect of deficit irrigation on yield and yield components of greenhouse tomato (Solanum lycopersicum) in hydroponic culture in Ahvaz region, Iran. Scientia Horticulturae, v.254, p.84-90, 2019. https://doi.org/10.1016/j.scienta.2019.04.084

IBRAHIM, E.A. Seed priming to alleviate salinity stress in germinating seeds. Journal of Plant Physiology, v.192, p.38-46, 2016. https://www.sciencedirect.com/science/article/pii/S0176161716000080

IBGE. Instituto Brasileiro de Geografia e Estatística. Levantamento Sistemático da Produção Agrícola. https://www.ibge.gov.br/ estatisticas-novoportal/economicas.html Accessed 19 June 2020.

KANG, G.; LI, G.; XU, W.; PENG, X.; HAN, Q.; ZHU, Y.; GUO, T. Proteomics reveals the effects of salicylic acid on growth and tolerance to subsequent drought stress in wheat. Journal of Proteome Research, v.11, n.12, p.6066-6079, 2012. https://doi.org/10.1021/ pr300728y

KONTOS, F.; SPYROPOULOS, C.G. Effect of linoleic, linolenic and jasmonic acid on the production of $\alpha$ - galactosidase and endo- $\beta$ mannanase in the endosperms of carob and fenugreek seeds. Journal of Plant Physiology, v.149, n.5, p.629-632, 1996. https://doi. org/10.1016/S0176-1617(96)80346-4

KUMAR, P.; ROUPHAEL, Y.; CARDARELLI, M.; COLLA, G. Vegetable grafting as a tool to improve drought resistance and water use efficiency. Frontiers in Plant Science, v.8, p.1130, 2017. https://doi.org/10.3389/fpls.2017.01130

LI, P.; CAI, Q.; WANG, H.; LI, S.; CHENG, J.; LI, H.; YU, Q.; WU, S. Hydrogen peroxide homeostasis provides beneficial microenvironment for SHR-mediated periclinal division in Arabidopsis root. New Phytologist, Accepted Manuscript, 2020. https://doi. org/10.1111/nph.16824

LI, X.; ZHANG, L. SA and PEG-Induced Priming for Water Stress Tolerance in Rice Seedling. In: ZHU, E.; SAMBATH, S. (Eds.). Information Technology and Agricultural Engineering: Advances in Intelligent and Soft Computing, v.134, Berlin, Heidelberg: Springer, 2012. p.881-887.

LOPES, C.A.; CARVALHO, M.L.M.; GUIMARÃES, R.M.; OLIVEIRA, A.M.S.; ANDRADE, D.B. Sodium hypochlorite in the priming of tobacco seeds. Journal of Seed Science, v.41, n.1, 108-111, 2019. https://dx.doi.org/10.1590/2317-1545v41n1211719

MAGUIRE, J.D. Speed of germination-aid in selection and evaluation for seedling emergence and vigor. Crop Science, v.2, p.176-177, 1962. https://doi.org/10.2135/cropsci1962.0011183X000200020033x

MARCOS-FILHO, J. Fisiologia de sementes de plantas cultivadas. 2nd ed. Londrina: ABRATES, 2015. 660p.

MHAMDI, A.; QUEVAL, G.; CHAOUCH, S.; VANDERAUWERA, S.; VAN BREUSEGEM, F.; NOCTOR, G. Catalase function in plants: A focus on Arabidopsis mutants as stress-mimic models. Journal of Experimental Botany, v.61, p.4197-4220, 2010. https://doi. org/10.1093/jxb/erq282

MOLES, T.M.; GUGLIELMINETTI, L.; REYES, T.H. Differential effects of sodium chloride on germination and post-germination stages of two tomato genotypes. Scientia Horticulturae, v.257, n.108730, 2019. https://doi.org/10.1016/j.scienta.2019.108730

MORAIS, T.C.; PINHEIRO, D.T.; MARTINEZ, P.A.H.; FINGER, F.L.; DIAS, D.C.F.S. Physiological and antioxidant changes in sunflower seeds under water restriction. Journal of Seed Science, v.42, n.e202042008, 2020. https://doi.org/10.1590/2317-1545v42225777

NAKAGAWA, J. Testes de vigor baseados no desempenho das plântulas. In: KRZYZANOSWKI, F.C.; VIEIRA, R.D.; FRANÇA-NETO, J.B. (Eds.). Vigor de sementes: conceitos e testes. Londrina: ABRATES, 1999. p. 2.1- 2.24

NAKANO, Y.; ASADA, K. Hydrogen peroxide is scavenged by ascorbate-specific peroxidase in spinach chloroplasts. Plant Cell Physiology, v.22, p.867-880, 1981. https://doi.org/10.1093/oxfordjournals.pcp.a076232

PEREIRA, W.D.L.; FILHO, P.A.M.; ALBUQUERQUE, M.B.; NOGUEIRA, R.J.M.C.; SANTOS, R.C. Mudanças bioquímicas em genótipos de amendoim submetidos a déficit hídrico moderado. Revista Ciência Agronômica, v.43, n.4, p.766-773, 2012. http://www.scielo.br/ scielo.php?script=sci_arttext\&pid=S1806-66902012000400019\&lng=en\&nrm=iso\&tlng=pt 
PIRES, R.M.O.; SOUZA, G.A.; CARDOSO, A.A.; DIAS, D.C.F.S.; BORGES, E.E.L. Action of nitric oxide in sesame seeds (Sesamum indicum L.) submitted to stress by cadmium. Journal of Seed Science, v.38, n.1, p.22-29, 2016. https://dx.doi.org/10.1590/2317$1545 v 38 n 1154824$

POKOTYLO, I.; KRAVETS, V.; RUELLAND, E. Salicylic Acid Binding Proteins (SABPs): The hidden forefront of salicylic acid signalling. International Journal of Molecular Sciences, v.20, n.18, p.4377, 2019. https://doi.org/10.3390/ijms20184377

RIVAS-SAN VICENTE, M.; PLASENCIA, J. Salicylic acid beyond defence: its role in plant growth and development. Journal of Experimental Botany, v.62, n.10, p.3321-3338, 2011. https://doi.org/10.1093/jxb/err031

RONGA, D.; RIZZA, F.; BADECK, F.W.; MILC, J.; LAVIANO, L.; MONTEVECCHI.; PECCHIONI, N.; FRANCIA, E. Physiological responses to chilling in cultivars of processing tomato released and cultivated over the past decades in Southern Europe. Scientia Horticulturae, v.231, p.118-125, 2018. https://doi.org/10.1016/j.scienta.2017.12.033

SAMOTA, M.K.; SASI, M.; AWANA, M.; YADAV, O.P.; AMITHA MITHRA, S.V.; TYAGI, A.; KUMAR, S.; SINGH, A. Elicitor-Induced biochemical and molecular manifestations to improve drought tolerance in rice (Oryza sativa L.) through seed-priming. Frontiers in Plant Science, v.8, p.934, 2017. https://doi.org/10.3389/fpls.2017.00934

SENARATNA, T.; TOUCHELL, D.; BUNN, E.; DIXON, K. Acetyl salicylic acid (Aspirin) and salicylic acid induce multiple stress tolerance in bean and tomato plants. Plant Growth Regulation, v.30, p.157-161, 2000. https://doi.org/10.1023/A:1006386800974

SHARAFIZAD, M.; NADERI, A.; ATA SIADAT, S.; SAKINEJAD, T.; LAK, S. Effect of salicylic acid pretreatment on germination of wheat under drought stress. Journal of Agricultural Science, v.5, n.3, 179-199, 2013. https://doi.org/10.5539/jas.v5n3p179

SHARMA, M.; GUPTA, S.K.; MAJUMDER, B.; MAURYA, V.K.; DEEBA, F.; ALAM, A.; PANDEY, V. Salicylic acid mediated growth, physiological and proteomic responses in two wheat varieties under drought stress. Journal of Proteomics, v.123, p.28-51, 2017. https://www.sciencedirect.com/science/article/pii/S1874391917301689

SHI, Y.; ZHANG, Y.; YAO, H.; WU, J.; SUN, H.; GONG, H. Silicon improves seed germination and alleviates oxidative stress of bud seedlings in tomato under water deficit stress. Plant Physiology and Biochemistry, v.78, p.27-36, 2014. https://doi.org/10.1016/j. plaphy.2014.02.009

SILVA, M.F.; ARAÚJO, E.F.; SILVA, L.J.; AMARO, H.T.R.; DIAS, L.A.S.; DIAS, D.C.F.S. Tolerance of crambe (Crambe abyssinica Hochst) to salinity and water stress during seed germination and initial seedling growth. Ciência e Agrotecnologia, v.43, e025418, 2019. http:// www.scielo.br/scielo.php?pid=S1413-70542019000100201\&script=sci_arttext\&tlng=en

SINGH, M.; VAISHALI SINGH, A.K.; KUMAR, A.; PANDEY, K.D. Molecular diversity of tomato germplasm (Lycopersicum esculentum L.) using lycopene specific markers. Biocatalysis and Agricultural Biotechnology, v.16, p.340-346, 2018. https://doi.org/10.1016/j. bcab.2018.08.017

VARIER, A.; VARI, A.K.; DADLANI, M. The subcellular basis of seed priming. Current Science, v.99, n.4, p.450-456, 2010. https://www. jstor.org/stable/24109568?seq=1

VELIKOVA, V.; YORDANOV, I.; EDREVA, A. Oxidative stress and some antioxidant systems in acid rain-treated bean plants. Plant Science, v.151, p.59-66, 2000. https://doi.org/10.1016/s0168-9452(99)00197-1

WOJTYLA, Ł.; LECHOWSKA, K.; KUBALA, S.; GARNCZARSKA, M. Different modes of hydrogen peroxide action during seed germination. Frontiers in Plant Science, v.7, n.66, 2016. https://doi.org/10.3389/fpls.2016.00066

YAMAMOTO, C.J.T.; LEITE, R.G.F.; MINAMIGUCHI, J.Y.; BRAGA, I.; MACHADO NETO, N.B.; CUSTÓDIO, C.C. Water-deficit tolerance induction during germination of Jalo Precoce bean (Phaseolus vulgaris L.) cultivar. Acta Physiologiae Plantarum, v.36, p.2897-2904, 2014. https://doi.org/10.1007/s11738-014-1659-9

YAN, M. Seed priming stimulate germination and early seedling growth of Chinese cabbage under drought stress. South African of Journal Botany, v.99, p.88-92, 2015. https://doi.org/10.1016/j.sajb.2015.03.195

ZHENG, M.; TAO, Y.; HUSSAIN, S.; JIANG, Q.; PENG, S.; HUANG, J.; CUI, K.; NIE, L. Seed priming in dry direct-seeded rice: consequences for emergence, seedling growth and associated metabolic events under drought stress. Plant Growth Regulation, v.78, p.167-178, 2016. https://doi.org/10.1007/s10725-015-0083-5 